\title{
Expression of interleukin I $\beta$ in gastric cancer tissue and its effects on gastric cancer
}

This article was published in the following Dove Press journal:

OncoTargets and Therapy

21 December 2015

Number of times this article has been viewed

\author{
Shenglu Yin \\ Chao Lan \\ Hui Pei \\ Zhiqiang Zhu \\ Emergency Center Department, First \\ Affiliated Hospital of Zhengzhou \\ University, Zhengzhou, People's \\ Republic of China
}

\begin{abstract}
This study detected the expression level of IL-1 $\beta$ in gastric cancer tissue and paracarcinoma tissue, and also analyzed its relationship with clinical and pathological features, so as to explore the expression of IL- $1 \beta$ in gastric cancer tissue and its effect on gastric cancer. A total of 70 fresh primary gastric cancer tumors and corresponding paracarcinoma tissues away from the tumor-incision edge $(\geq 5 \mathrm{~cm})$ were selected from the First Affiliated Hospital of Zhengzhou University from January to December 2014. Total protein concentration was extracted from tissues with radioimmunoprecipitation assay lysis buffer, and IL-1 $\beta$ content in tissues was detected with enzyme-linked immunosorbent assay. The ratio of cell cytokine content and protein concentration was considered as the relative content of cytokines, and the relationship between relative content of cytokines and clinical data was analyzed. Results indicated that the differences in content of IL-1 $\beta$ in gastric cancer tissues and paracarcinoma tissues had no statistical significance, but the content of IL- $1 \beta$ would rise as tumor size was enlarged, based upon analysis $(2.9<4.2 \mathrm{ng} / \mathrm{g})$, and the difference was statistically significant $(P<0.05)$. Furthermore, IL-1 $\beta$ content decreased along with differentiation degree and infiltration depth $(3.21<4.15 \mathrm{ng} / \mathrm{g}, 3.06<3.45 \mathrm{ng} / \mathrm{g})$, but the difference was not statistically significant $(P>0.05)$. Therefore, it can be concluded that IL-1 $\beta$ plays an important role in the occurrence and development of gastric cancer and promotes the treatment of gastric cancer to some extent.
\end{abstract}

Keywords: interleukin cytokines, paracarcinoma tissues, Helicobacter pylori, enzyme-linked immunosorbent assay

\section{Introduction}

Gastric cancer, a common malignant tumor worldwide, has the second-highest death rate among malignant tumors. ${ }^{1}$ In the People's Republic of China, its morbidity ranks second in the national malignant tumor-registration area $(32.23 / 100,000)$ and its death rate ranks third $(23.90 / 100,000){ }^{2}{ }^{2}$ Recently, the death rate of gastric cancer was still ranked top in some countries and areas, although morbidity had fallen to some extent, with a 5 -year survival rate of 5\%-10\%. ${ }^{3-8}$ Therefore, the occurrence and development mechanism of gastric cancer is of great significance in its prevention and treatment. A variety of studies confirm that there are many factors that cause gastric cancer, and the occurrence of gastric cancer is a process involving multiple conditions and external reasons, including various genetic mutations. In 1994, the World Health Organization officially announced that Helicobacter pylori (HP) was a risk factor leading to gastric cancer. ${ }^{9}$ HP infection has diverse influences on the occurrence of gastric cancer in different individuals, which is believed to be related to genetic factors of the infected person. Some studies verify that IL-1 $\beta$ is correlated with the promotion of gastric cancer after HP infection, ${ }^{10}$ and a large number of epidemiological, genetic, and molecular biology studies have confirmed that persistent chronic inflammation plays vital roles in activating, maintaining, and promoting the growth of gastric cancer. IL-1 $\beta$, a kind
Correspondence: Shenglu Yin Emergency Center Department, First Affiliated Hospital of Zhengzhou University, No I Jianshe East Road, Zhengzhou, Henan 450052, People's Republic of China Email yinshenglu999@163.com 
of proinflammatory cytokine, regulates a variety of mechanisms, such as inflammatory immune injury and epigenetic changes, and also has strong effects in inhibiting gastric acid secretion, gathering bone marrow cells, and promoting angiogenesis, which is closely associated with the development of HP-infected gastric mucosal lesions and atrophic gastritis, as well as the occurrence of gastric cancer. ${ }^{11}$

People's understanding of IL-1 $\beta$ and HP is deepening as modern medical techniques develop continuously. IL- $1 \beta$ influences the occurrence and development of gastric cancer, mainly through inhibiting gastric acid secretion, inducing changes in epigenetics, collecting bone marrow cells, promoting angiogenesis, luring adhesive factor, and releasing other inflammatory factors. IL- $1 \beta$ has a strong effect in inhibiting gastric acid secretion, and the gastric acid secretion-inhibition capacity of IL-1 $\beta$ ( $1 \mathrm{~g}$ molecule) is equal to 100 times that of omeprazole (proton-pump inhibitor) and 6,000 times that of cimetidine at the same dose. It is assumed that IL-1 $\beta$ is capable of causing gastratrophy and increasing the risk of gastric cancer, due to its strong acidsuppression effect. IL- $1 \beta$ has been found to have a key role in the occurrence and development of tumors: on the one hand, it takes part in the transformation, growth, invasion, and metastasis of malignant tumors; on the other hand, it is able to activate the body's immune system to limit the growth of tumors. ${ }^{12}$ To date, the effect of IL-1 $\beta$ on the occurrence and development of tumors is still in dispute. This paper discusses the influence of IL-1 $\beta$ level on the occurrence and development and treatment of gastric cancer by analyzing the correlation between IL- $1 \beta$ level and clinical features in gastric cancer.

\section{Materials and methods Patient clinical data}

In total, 70 patients who had undergone gastric cancer operations in the First Affiliated Hospital of Zhengzhou University from January to December 2014 were selected, of which 50 were male (average age 61.5 \pm 10.5 years). None of them had received any radio- or chemotherapy before the operation. According to gastric cancer tumor node metastasis (TNM) staging (2010) issued by the American Joint Committee on Cancer, patients were divided as follows: stage I-II (25 cases), stage III-IV (45 cases), radical operation (65 cases), and palliative operation (five cases). Fresh tumor tissues and corresponding paracarcinoma tissues away from the tumor-incision edge $(\geq 5 \mathrm{~cm})$ were frozen immediately with liquid nitrogen after excision and preserved in the refrigerator at $-80^{\circ} \mathrm{C}$ for standby application. This experiment was examined and approved by the ethics committee of the First
Affiliated Hospital of Zhengzhou University, and all patients signed informed consent forms.

\section{Sample collection}

Venous blood was collected from all subjects with an empty stomach in the early morning, some of which was used for HP-antibody detection and the other part for $1 \mathrm{~L}-1 \beta$ genome DNA extraction.

Firstly, tumor and paracarcinoma tissues stored in the refrigerator $\left(-80^{\circ} \mathrm{C}\right)$ were taken out and added to $1 \mathrm{~mL}$ powerful radioimmunoprecipitation assay lysis buffer (Beyotime, Shanghai, People's Republic of China), and then they were homogenized with a biological sample homogenizer (Precellys ${ }^{\circledR} 24$; Bertin Technologies, Montignyle-Bretonneux, France) and centrifuged at $4{ }^{\circ} \mathrm{C}$. Afterward, clear liquid was taken and preserved in the refrigerator at $-80^{\circ} \mathrm{C}$ in subpackages.

\section{Clinical pathological parameters of gastric cancer}

A total of 70 gastric cancer surgical specimens were compared according to sex (male/female), age ( $<50$ years), tumor size $(<5 \mathrm{~cm}$ and $\geq 5 \mathrm{~cm}$ ), tumor site (fundus of stomach, gastric body, and antrum of stomach), serosal invasion (mucosa and muscular layer, serous membrane, and outside), blood-vessel infiltration (with and without), lymphatic infiltration (with and without) and differentiation degree (high, moderate, and low).

\section{Experimental methods}

First, protein concentration was tested as per the instructions of a bicinchoninic acid kit (Thermo Fisher Scientific, Waltham, MA, USA), and then the ratio of cytokine content and sample protein concentration, ie, the relative content of cell cytokines, was detected with enzyme-linked immunosorbent assay (ELISA). The IL-1 $\beta$ detection kit came from Thermo Fisher Scientific, and the microplate reader was from Tecan Safire2 ${ }^{\mathrm{TM}}$ (Männedorf, Switzerland). The selected tissue protein was unfrozen first, and standard substance was diluated twice, then $50 \mu \mathrm{L}$ was taken and added to the commercialized ELISA plate. Each well had with $100 \mu \mathrm{L}$ biotin antibodies added and was incubated at room temperature for 2 hours. After the liquid was taken out, wells were washed four times continuously using $400 \mu \mathrm{L}$ scrubbing solution, beaten repeatedly, and sucked dry with filter paper. Afterward, wells were added to $100 \mu \mathrm{L}$ streptavidin-horseradish peroxidase working liquid and incubated for 30 minutes at room temperature. Then, wells were washed four times repeatedly and beaten dry after the liquid was taken out. After $100 \mu \mathrm{L}$ color-substrate 
solution was added, wells were incubated for 30 minutes at room temperature, and finally $100 \mu \mathrm{L}$ stop buffer was added to terminate the enzyme reaction.

\section{Detection methods}

A whole-blood DNA-extraction kit was used for genome DNA extraction, polymerase chain-reaction amplification, and $1 \mathrm{~L}-1 \beta-51$ and $1 \mathrm{~L}-1 \beta-31$ loci detection. Also, restriction enzyme digestion and electrophoresis were performed on gene-amplification products.

\section{Statistical methods}

SPSS 13.0 software was used for statistical analysis, abnormally distributed experimental data were subjected to Wilcoxon rank-sum and $H$-tests and expressed as medians, and $t$-tests and one-way analyses of variance were carried out on normally distributed data and expressed as means \pm standard deviation. Differences were considered to be statistically significant if $P<0.05$.

\section{Results}

\section{IL-I $\beta$ content in tumor tissue and paracarcinoma tissue}

Of 70 tumor tissues in patients with gastric cancer, IL-1 $\beta$ content $(2.66 \mathrm{ng} / \mathrm{g})$ had no statistical difference in tumor tissues and paracarcinoma tissues (Table 1).

\section{Relationship between IL- I $\beta$ content and clinical and pathological features in tumor tissues}

Of 70 gastric cancer samples, IL-1 $\beta$ content rose as tumor size enlarged, and the difference was statistically significant $(P<0.05)$; however, there was no statistical significance in different ages, blood types, sexes, number of lymph-node metastases, tumor sites, or TNM staging ( $P>0.05$, Table 2$)$.

\section{Relationship between HP infection and gastric cancer}

Positive rates of HP infection in the gastric cancer group and control group were $75.7 \%$ and $24.3 \%$, respectively, and comparative differences between the groups were statistically significant $\left(\chi^{2}=19.61, P<0.05\right)$. Also, patients with positive HP infection were twice as likely to develop gastric cancer compared with negatively infected patients. Details are shown in Table 3.

\section{Distribution and comparison of IL-I $\beta-3 \mid$ genotype}

The distributional difference of three genotypes in the two groups showed statistical significance $\left(\chi^{2}=10.31, P<0.05\right)$ : the $\mathrm{C} / \mathrm{T}$ and $\mathrm{T} / \mathrm{T}$ genotypes were twice and three times as likely to develop gastric cancer in comparison with the $\mathrm{C} / \mathrm{C}$ genotype. Please refer to Table 4.

\section{Influence of interactive relationship between HP infection and genotype on gastric cancer}

HP infection together with genotype jointly decided the risk of the occurrence of gastric cancer, and positively infected patients carrying $\mathrm{T} / \mathrm{T}$ were twice as likely to suffer from gastric cancer compared with negatively infected patients carrying $\mathrm{C} / \mathrm{C}+\mathrm{C} / \mathrm{T}$. Details are displayed in Table 5 .

\section{Discussion}

The IL1 gene was found to be located in human chromosome 2q13-14 in 1972, with a total length of approximately $430 \mathrm{~kb}$. The IL1 gene was known as lymphocyte-activating factor at the very start, because it acted as a lymphocytic mitotic factor. Thereafter, studies discovered that IL-1 was made up of IL-1 $\alpha$, IL-1 $\beta$, and IL-1 receptor antagonists, in which the $I L 1 B$ gene was one of the most important members of the family, including 153 amino acid residues and excluding disulfide bonds. However, two cysteine residues are essential for IL-1 $\beta$ activity. ${ }^{13}$ Other studies ${ }^{14-16}$ found that IL-1 $\beta$ was closely associated with the occurrence of multiple malignant tumors, eg, esophageal cancer, lung cancer, colon cancer, cervical cancer, breast cancer, and prostate cancer. Similarly, the expression of IL- $1 \beta$ in gastric cancer increased obviously. Through testing three kinds of cytokines (IL-1 $\beta$, $\mathrm{TNF} \alpha$, and IL-8) in serum in patients with gastric cancer, Macrì et $\mathrm{al}^{17}$ figured out that the expression levels of these three cytokines were apparently higher than those of the normal control group. Therefore, those three indices were believed to be gastric cancer markers used for detecting the occurrence of gastric cancer.

IL-1 $\beta$ not only expresses highly in gastric cancer tissues but also is notably correlated with clinical and pathological

Table I IL-I $\beta$ content in tumor tissue and paracarcinoma tissue

\begin{tabular}{|c|c|c|c|c|c|}
\hline Cell cytokine & Sample size & $\begin{array}{l}\text { Cell cytokine content } \\
\text { in cancer tissue }\end{array}$ & $\begin{array}{l}\text { Cell cytokine content in } \\
\text { paracarcinoma tissue }\end{array}$ & $\begin{array}{l}\text { Pair comparison of } \\
\text { Z-value of rank-sum test }\end{array}$ & $P$-value \\
\hline IL-I $\beta$ & 70 & 3.45 & 2.66 & -3.20 & $<0.01$ \\
\hline
\end{tabular}


Table 2 Relationship between IL- I $\beta$ content and clinical and pathological features in tumor tissues

\begin{tabular}{|c|c|c|c|c|}
\hline \multirow{2}{*}{$\begin{array}{l}\text { Clinical and pathological } \\
\text { features }\end{array}$} & \multirow{2}{*}{$\begin{array}{l}\text { Sample } \\
\text { size }\end{array}$} & \multicolumn{3}{|l|}{ IL-I $\beta$} \\
\hline & & IL-I $\beta$ level & Test statistics & $P$-value \\
\hline \multicolumn{5}{|l|}{ Age, years } \\
\hline$>60$ & 37 & 3.81 & -0.09 & 0.92 \\
\hline$\leq 60$ & 33 & 3.50 & & \\
\hline \multicolumn{5}{|l|}{ Sex } \\
\hline Male & 52 & 3.59 & -0.69 & 0.48 \\
\hline Female & 18 & 4.04 & & \\
\hline \multicolumn{5}{|l|}{ Blood type } \\
\hline$A$ & 25 & 3.59 & 1.56 & 0.66 \\
\hline B & 13 & 3.06 & & \\
\hline O & 22 & 4.91 & & \\
\hline$A B$ & 10 & 2.79 & & \\
\hline \multicolumn{5}{|l|}{ Differentiated degree } \\
\hline Stage I-II & 24 & 4.15 & -0.87 & 0.38 \\
\hline Stage III & 46 & 3.21 & & \\
\hline \multicolumn{5}{|l|}{ Invasion depth } \\
\hline $\mathrm{TI}-\mathrm{T} 2$ & 12 & 3.45 & -1.15 & 0.24 \\
\hline T3-T4 & 58 & 3.06 & & \\
\hline \multicolumn{5}{|l|}{ Number of lymph-node } \\
\hline \multicolumn{5}{|l|}{ metastases } \\
\hline No $(0)$ & 15 & 3.31 & 0.80 & 0.84 \\
\hline$N I(I-2)$ & 9 & 3.13 & & \\
\hline N2 (3-6) & 28 & 3.59 & & \\
\hline N3 $(\geq 7)$ & 18 & 5.30 & & \\
\hline \multicolumn{5}{|l|}{ Diameter of tumor } \\
\hline$\geq 5 \mathrm{~cm}$ & 45 & 3.21 & -2.16 & 0.03 \\
\hline$<5 \mathrm{~cm}$ & 25 & 3.80 & & \\
\hline \multicolumn{5}{|l|}{ Tumor site } \\
\hline Antrum of stomach & 50 & 3.45 & 0.64 & 0.72 \\
\hline Gastric body & 10 & 6.00 & & \\
\hline Cardia of stomach & 10 & 3.16 & & \\
\hline \multicolumn{5}{|l|}{ TNM staging } \\
\hline I-II & 25 & 3.15 & -0.30 & 0.76 \\
\hline
\end{tabular}

features of gastric cancer. The elimination of HP infection has been widely accepted, as the occurrence and development of gastric cancer have an intimate connection with inflammation, and HP infection plays a key role in it. ${ }^{18}$ Patients infected with HP exceed those without infection markedly in the incidence of gastric cancer, as both cell apoptosis and proliferation in HP-infected gastric antral mucosa increase, and the increasing extent is closely related to the degree of inflammation. In the occurrence and development of gastric cancer, HP is likely to cause the imbalance of gastric

Table 3 Distribution and constituent ratio of Helicobacter pylori (HP) infection in the two groups (\%)

\begin{tabular}{llllll}
\hline HP & \multicolumn{2}{l}{ Gastric cancer group } & & \multicolumn{2}{l}{ Control group } \\
\cline { 2 - 3 } \cline { 5 - 6 } infection & Number & Constituent & & Number & Constituent \\
& of cases & ratio & & of cases & ratio \\
\hline Negative & 17 & 24.3 & & 34 & 48.6 \\
Positive & 53 & 75.7 & & 17 & 24.4 \\
\hline
\end{tabular}

mucosa epithelial cell proliferation and apoptosis, induce abnormal gastric mucosa through promoting the abnormal expression of some regulatory genes, and finally lead to gastric cancer.

The relationship between inflammation and tumors has become a research hot spot since Balkwill and Mantovani ${ }^{19}$ originally found relevance existing in chronic inflammation and cancerization. A study ${ }^{20}$ has verified that chronic inflammation plays a part in three stages, ie, the start, proliferation, and progress of the tumor formation.

Table 4 Distribution and constituent ratio of IL-I $\beta$-3 I genotype in the two groups (\%)

\begin{tabular}{|c|c|c|c|c|}
\hline \multirow[t]{2}{*}{ Genotype } & \multicolumn{2}{|c|}{ Gastric cancer group } & \multicolumn{2}{|c|}{ Control group } \\
\hline & $\begin{array}{l}\text { Number } \\
\text { of cases }\end{array}$ & $\begin{array}{l}\text { Constituent } \\
\text { ratio }\end{array}$ & $\begin{array}{l}\text { Number } \\
\text { of cases }\end{array}$ & $\begin{array}{l}\text { Constituent } \\
\text { ratio }\end{array}$ \\
\hline $\mathrm{C} / \mathrm{C}$ & 5 & 7.1 & 20 & 28.6 \\
\hline $\mathrm{C} / \mathrm{T}$ & 38 & 54.3 & 33 & 47.1 \\
\hline $\mathrm{T} / \mathrm{T}$ & 27 & 38.6 & 17 & 24.3 \\
\hline
\end{tabular}


Table 5 Correlation between interaction of Helicobacter pylori (HP) infection and genotype and gastric cancer (cases)

\begin{tabular}{llllll}
\hline $\begin{array}{l}\text { HP } \\
\text { infection }\end{array}$ & Genotype & $\begin{array}{l}\text { Gastric cancer } \\
\text { group }\end{array}$ & $\begin{array}{l}\text { Control } \\
\text { group }\end{array}$ & OR & $\mathbf{9 5 \%} \mathbf{C l}$ \\
\hline- & $\mathrm{C} / \mathrm{C}+\mathrm{C} / \mathrm{T}$ & 6 & 35 & $\mathrm{I} .00$ & $\mathrm{I} .00$ \\
- & $\mathrm{T} / \mathrm{T}$ & 10 & $\mathrm{II}$ & $\mathrm{I} .14$ & $0.55-2.03$ \\
+ & $\mathrm{C} / \mathrm{C}+\mathrm{C} / \mathrm{T}$ & 30 & $\mathrm{I}$ & 0.58 & $0.34-1.36$ \\
+ & $\mathrm{T} / \mathrm{T}$ & 24 & 8 & 2.87 & $1.57-3.07$ \\
\hline
\end{tabular}

Abbreviations: $\mathrm{OR}$, odds ratio; $\mathrm{Cl}$, confidence interval.

Furthermore, current research focuses more on cytokines and the main function of the cytokines soluble medium in tumor activation, rather than the nature of immune-cell infiltration. IL- $1 \beta$, a core element in the inflammatory medium, turns into a key factor affecting the occurrence and development of gastric cancer, but its mechanism in gastric cancer is still not fully understood. Therefore, further studying IL-1 $\beta$ could provide a novel way of revealing the pathogenesis of gastric cancer.

To sum up, obviously high IL-1 expression level in tumor tissues is intimately associated with the occurrence and development of tumors. Results obtained from this study demonstrate that IL- $1 \beta$ as a core element in the inflammatory medium affects the occurrence and development of gastric cancer profoundly, but its mechanism in gastric cancer is still not fully understood. Therefore, looking for IL- $1 \beta$ expression and cancer-promotion mechanisms is expected to become a new target for the treatment of IL- $1 \beta$ and its receptor, thus further controlling the occurrence, development, and metastasis of gastric cancer.

\section{Disclosure}

The authors report no conflicts of interest in this work.

\section{References}

1. Ferlay J, Shin HR, Bray F, Forman D, Mathers C, Parkin DM. Estimates of worldwide burden of cancer in 2008: GLOBOCAN 2008. Int J Cancer. 2010;127(12):2893-2917.

2. Jie H, Ping Z, Qing CW. 2011 Chinese Cancer Registy Annual Report. Beijing: China Press; 2012.

3. Ito K, Liu Q, Salto-Tellez M, et al. RUNX3, a novel tumor suppressor, is frequently inactivated in gastric cancer by protein mislocalization. Cancer Res. 2005;65(17):7743-7750.

OncoTargets and Therapy

\section{Publish your work in this journal}

OncoTargets and Therapy is an international, peer-reviewed, open access journal focusing on the pathological basis of all cancers, potential targets for therapy and treatment protocols employed to improve the management of cancer patients. The journal also focuses on the impact of management programs and new therapeutic agents and protocols on
4. Sato F, Meltzer SJ. CpG island hypermethylation in progression of esophageal and gastric cancer. Cancer. 2006;106(3):483-493.

5. Ottini L, Falchetti M, Lupi R, et al. Patterns of genomic instability in gastric cancer: clinical implications and perspectives. Ann Oncol. 2006; 17 Suppl 7:vii97-vii102.

6. Shang J, Pena AS. Multidisciplinary approach to understand the pathogenesis of gastric cancer. World J Gastroenterol. 2005;11(27):4131-4139.

7. Kusano M, Toyota M, Suzuki H, et al. Genetic, epigenetic, and clinicopathologic features of gastric carcinomas with the $\mathrm{CpG}$ island methylator phenotype and an association with Epstein-Barr virus. Cancer. 2006; 106(7):1467-1479.

8. Fang JY, Cheng ZH, Chen YX, et al. Expression of Dnmtl, demethylase, $\mathrm{MeCP} 2$ and methylation of tumor-related genes in human gastric cancer. World J Gastroenterol. 2004;10(23):3394-3398.

9. Baojian Z, Yuanneng C, Tao Z. [Effect of Qingre Huashi detection on regulating SGC-7901 cell apoptosis by mediating CD-14 and IL-1 $\beta$ for prevention and treatment of colon cancer]. Zhongguo Shi Yan Fang Ji Xие Za Zhi. 2013;19(20):246-250. Chinese.

10. Hui L, Jianmin D, Xiaoyu L. Influence of TNF- $\alpha$ and IL-1 $\beta$ on expression of mesothelial cell adhesion molecule mRNA in stomach membrane. Chin J Gastroenterol Hepatol. 2014;23(3):252-255.

11. Chakravorty M, Ghosh A, Choudhury A, Santra A, Hembrum J, Roychoudhury S. Ethnic differences in allele distribution for the IL8 and IL1B genes in populations from eastern India. Hum Biol. 2004;76(1): 153-159.

12. Apte RN, Dotan S, Elkabets M, et al. The involvement of IL-1 in tumorigenesis, tumor invasiveness, metastasis and tumor-host interactions. Cancer Metastasis Rev. 2006;25(3):387-408.

13. Dongqiang H, Yumin L, Tao L. [Advance in research on relation between interleukin-1 $\beta$ and gastric cancer]. Zhongguo Pu Wai Ji Chu Yu Lin Chuang Za Zhi. 2012;19(11):1249-1254. Chinese.

14. Chen MF, Lu MS, Chen PT, Chen WC, Lin PY, Lee KD. Role of interleukin $1 \beta$ in esophageal squamous cell carcinoma. J Mol Med (Berl). 2012; 90(1):89-100.

15. Al-Tahhan MA, Etewa RL, El Behery MM. Association between circulating interleukin-1 beta (IL-1 $\beta$ ) levels and IL- $1 \beta$ C-511T polymorphism with cervical cancer risk in Egyptian women. Mol Cell Biochem. 2011;353(1-2):159-165.

16. Elaraj DM, Weinreich DM, Varghese S, et al. The role of interleukin 1 in growth and metastasis of human cancer xenografts. Clin Cancer Res. 2006;12(4):1088-1096.

17. Macrì A, Versaci A, Loddo S, et al. Serum levels of interleukin $1 \beta$, interleukin 8 and tumor necrosis factor $\alpha$ as markers of gastric cancer. Biomarkers. 2006;11(2):184-193

18. Malfertheiner P, Mégraud F, O'Morain C, et al. Current concepts in the management of Helicobacter pylori infection - the Maastricht 2-2000 Consensus Report. Aliment Pharmacol Ther. 2002;16(2):167-180.

19. Balkwill F, Mantovani A. Inflammation and cancer: back to Virchow? Lancet. 2001;357(9255):539-545.

20. Hussain SP, Harris CC. Inflammation and cancer: an ancient link with novel potentials. Int J Cancer. 2007;121(11):2373-2380.

patient perspectives such as quality of life, adherence and satisfaction. The manuscript management system is completely online and includes a very quick and fair peer-review system, which is all easy to use. Visit http://www.dovepress.com/testimonials.php to read real quotes from published authors. 